\title{
Civilisations
}

Revue internationale d'anthropologie et de sciences

humaines

$62 \mid 2013$

Identité, culture et intimité

\section{“Ţiganu-i Ţigan”}

Verbal Icons and Urban Marginality in a Post-Socialist European City

\section{Giovanni Picker}

\section{(2) OpenEdition}

Journals

\section{Electronic version}

URL: http://journals.openedition.org/civilisations/3271

DOI: 10.4000/civilisations.3271

ISSN: 2032-0442

\section{Publisher}

Institut de sociologie de l'Université Libre de Bruxelles

\section{Printed version}

Date of publication: 31 December 2013

Number of pages: $51-70$

ISBN: 2-87263-042-2

ISSN: 0009-8140

\section{Electronic reference}

Giovanni Picker, " "Țiganu-i țigan" », Civilisations [Online], 62 | 2013, Online since 31 December 2016, connection on 19 April 2019. URL : http://journals.openedition.org/civilisations/3271 ; DOI : 10.4000/ civilisations. 3271

(C) Tous droits réservés 


\title{
"T,iganu-i țigan" \\ Verbal Icons and Urban Marginality in a Post-Socialist European City
}

\author{
Giovanni PICKER
}

\begin{abstract}
Social science studies have not often looked at the links between broad dynamics of social closure and everyday local idioms of difference in post-socialist Europe. In this article I give a theoretical and empirical contribution to research on the links between "cultural intimacy" and urban marginality in times of massive neoliberal restructuring in the region. Drawing on fieldwork in Cluj-Napoca (Romania) I ethnographically investigate the everyday working of two verbal icons indexing peculiar characterizations of Roma, and I discuss the multiple ways through which they contribute to informing policy making, and ultimately to perpetuating the conditions of social marginality and segregation under which a significant number of Romani families live. Civil servants and the workers of a periphery neighbourhood articulate those icons in different ways, yet similarly constructing a space of cultural intimacy that functions both as a vector of exclusion of Roma from the ethno-moral boundaries of the nation, and, creatively, as a type of sociality securing a certain distance from the $E U$ gaze and its discourse of tolerance.
\end{abstract}

Keywords: urban marginality, cultural intimacy, iconicity, Roma, policy, Romania, post-socialist Europe.

Résumé : Les études en sciences sociales se penchent rarement sur les liens entre les dynamiques de fermeture sociale et les idiomes quotidiens de la différence dans l'Europe postsocialiste. Dans cet article, l'auteur propose une contribution théorique et empirique sur les connexions entre l'intimité culturelle' et la marginalité urbaine à l'ère de la restructuration néolibérale massive dans la région de Cluj-Napoca (Roumanie). Il étudie plus précisément les usages quotidiens de deux expressions iconiques relatives aux Roms et cherche à dégager les façons dont elles contribuent à l'élaboration de politiques publiques et à la perpétuation de conditions sociales marginales et de ségrégation pour beaucoup de familles roms. Les fonctionnaires et autres travailleurs d'une région périphérique emploient de façons différentes ces expressions. Cependant, celles-ci permettent de construire un espace d'intimité culturelle qui agit comme vecteur d'exclusion des Roms au-delà des frontières ethniques et morales de la nation, et comme un type de socialité qui assure une certaine mise à l'écart du regard de l'Union Européenne et de son discours sur la tolérance.

Mots-clés : marginalité urbaine, intimité culturelle, icônicité, Rom, politiques publiques, Roumanie, postsocialisme.

1 This work was possible with the financial support of the Sectoral Operational Programme for Human Resources Development 2007-2013, co-financed by the European Social Fund, under the project number POSDRU/89/1.5/S/61104 with the title "Social sciences and humanities in the context of global development - development and implementation of postdoctoral research." I wish to thank Krista Harper and Shannon Woodcock for their helpful remarks during the 2009 ASN World Convention at Columbia University where I presented a first draft of this article. I am also thankful to Jon Fox, Marta Bolognani, Will Guy, Gabi Maas, Catalina Tesar, Sandy Ross and Ioana Vrabiescu for our discussions on topics related to the article and for their insightful comments on a later draft. Special thanks also to two anonymous reviewers of Civilisations. 


\section{Introduction}

Since I arrived in Cluj-Napoca in January 2011, around the $10^{\text {th }}$ of each month I regularly queue at the Rom Telecom headquarters in the city centre, in order to pay my Internet bills. While the 1960s geometric decoration of the grey, austere building façade of the headquarters reminds the passerby of a celebration of socialist scientific progress, the open-space white-and-blue office is a hymn to $21^{\text {th }}$ century design. In August, the presence of air conditioning reinvigorates this contrasting feeling. At the entrance I receive from an electronic machine a ticket with a number in big font, and - smaller, underneath - the number of people waiting to be served before me: 13 . I decide to sit on one of the leather-like sofas. As my number is approaching, I start walking towards the cashier, where now only one person is in front of me. As my number appears on a display, a woman suddenly jumps the queue and rushes to the cashier. I just have the time to think "Never mind, I can wait a couple more minutes", when I see the hands of a man not beyond his forties reaching the lady's left shoulder and quickly turning her back. Visibly intimidated by the man's vehemence, the lady steps back to the end of the queue. Taken by surprise, I hesitate, when the man orders me to proceed to the cashier. I do that, and after paying my bill, I move towards the exit door, wondering why he reacted so forcefully. Once he pays his own bills, he approaches me, looks with cynicism into my eyes, and says "Thiganu-i tigan" - literally, "Gypsies will be Gypsies" - and rapidly walks through the exit door, leaving me behind.

The fast capitalist reorganization of society refracting in the urban architecture, and the everyday stigmatization of Roma are two mutually rising phenomena in contemporary Romania. The polarized aesthetics featuring of, on the one hand, the austerity of the façade of the Rom Telecom headquarters and, on the other hand, its high-tech interiors is a visual sign of the post-socialist Romanian economy, ${ }^{2}$ which has increasingly producing social inequalities. As from 1998 to 2005 income per capita constantly increased, in the same period the rate of income inequality also steadily increased (UNDP 2007). ${ }^{3}$ And since 1989 discrimination against Roma, although not steadily increasing, has reached relatively high levels (Soros Foundation 2011). As studies in other parts of Europe suggest, in the case of Roma the two phenomena of socio-economic marginality and everyday idiom of difference are often connected (Okely 1983: 28-37; Picker 2010; 2011; Sigona \& Trehan 2009). A sign of their mutual persistence is that the European Roma Policy, since the Lisbon Treaty, signed in 2000, has moved towards tackling conjointly these two phenomena, which are phrased in the policy vocabulary as "social exclusion" and "discrimination" (Mc Garry 2010: 59-79). Past the mid-2000s end of flows of EU subsidies to candidate States, urban policies towards Roma in Romania took a neoliberal turn, which is having the consequence of segregating many of them at the edges of urban peripheries (Berescu 2011). This contributes to reinforce a local idiom viewing Roma as incapable of catching up with

2 By using the terms "post-socialist" and "post-socialism" I am aware of the reified meaning they carry (as Tulbure 2009 suggests). However, I use them only to allude to a historical and macro-economic change.

3 Moreover, in comparison with all other EU member states, Romania ranks first for employed persons at risk of poverty (EUROSTAT 2009). 
"normal" standards of living. In the following ethnographic account I will outline an instance of such idiom in the context of a housing relocation policy.

This article is positioned at the intersection of two research streams. On the one hand, studies of the impact of post-socialist socio-economic transformations on Roma; on the other hand, studies focusing on post-socialist everyday processes of identification and differentiation. Studies belonging to the first stream focus on social marginality, stressing the emerging phenomenon of "ethnicization of poverty" (Peter 2005); others comparatively focus on the intersection between culture of poverty and economic conditions in Hungary, Romania and Bulgaria (Ladanyi \& Szelenyi 2006); finally, postsocialist transition processes have been scrutinized as negatively impacting already marginalized categories of population, including Roma (Emigh et al. 2001). As for the second stream, the everyday idiom of cultural difference is the topic of studies carried out in the territories of the former Yugoslavia (Bringa 1996; Jansen 2003); in Hungary (Horvath 2010; Kovai 2010) and in Romania (Brubaker et al. 2006; Kligman 2001). They show the extent to which political and macro-economic events can seep into daily social perceptions and actions. Interestingly, and surprisingly, among the latter stream of studies, only Gail Kligman (2001) focuses on the case of Romanian Roma.

In this article I draw on these two research streams in order to contribute to the empirical knowledge of the intersections of marginality and everyday idiom of difference in post-socialist Europe. My question is about how the everyday idiom of difference is linked to marginality and I will focus on the case of marginalized Roma in Romania. After introducing my main theoretical and historical references, I will outline my ethnography and in the third part I will discuss my findings in light of my theoretical and historical framework.

\section{Iconicity and history}

In local knowledge, the expression Thiganu-i tigan, ${ }^{4}$ which the man at the Rom Telecom headquarters used, articulates an idea of predetermination, suggesting that Roma will never change; indeed, its proper translation is, "once a Gypsy, always a Gypsy!" (see also Stewart 2010: 2). The rooted history of stereotyped images of Roma in Europe and beyond (e.g. Lemon 2000; Piasere 2006; Willelms 1997) allows this expression to gain everyday currency. The peculiar ways in which these images circulate in the Romanian context can be viewed as an instance of "iconicity" (Herzfeld 1997: 93-110). Iconicity refers to the process of creating icons - that is, static images resembling specific objects, individuals, or other beings - that index peculiar meanings easily understandable to those who are familiar with the context in which the icon was shaped. Iconicity is based on the semiotic principle of resemblance, which works by means of allusion. "And allusion, being indirect, discourages critical dissection" (Ibid.: 104), because of its ideological effect of presenting itself as a self-evident truth. This article is an ethnographic "critical dissection" of an instance of iconicity.

During my fieldwork in Cluj I came across two major verbal icons for identifying Roma in everyday life, namely Ţiganu-i țigan and mentalitate (literally "mentality'). I

4 As it will become clear in the next sections, "Țigan" is hardly translatable with "Gypsy" due to its peculiar place in Romanian history. Therefore, throughout the text I will keep using the term Tुigan. 
view these two expressions as icons, namely static, eternal and unchangeable images which in the social imagination resemble Roma and which index moral values related to laziness, avoidance of work, and a more general backwardness. While mentalitate is mostly used for theorizing what appears as self-evident truth, Tiganu-i ţigan is mostly used in a less analytical way for confirming the self-fulfilling prophecy of an allegedly unchangeable deviant and lazy character of Roma. At the same time, both function as mechanisms of demarcating - and efficiently preventing questioning - the ethno-moral boundaries of the nation.

The two icons must be understood within long-term Romanian cultural histories, and their current use largely comes from the articulation of a powerful East-West asymmetrical dichotomy in the national social imagination. As Heintz (2002) lucidly points out, in Romania there is an "exaggerated respect for everything that is Western" (Ibid.: 11) including the popular belief that only in the West is civilization possible. This discourse might be seen as a sort of internalization of what Todorova (1997) called "Balkanism", namely the Western attitude of considering the Balkans, and in general "the East", the backward region of Europe in which the enlightening superiority of Western values is absent (see also Cioroianu 2002). Heintz (2002; 2004) ethnographically discloses that the expression "Romanian mentality" in everyday life refers to the reason that Romanians attribute to the backwardness of their own work ethic. This backwardness is the ultimate reason for the economic inferiority of Romania vis-à-vis the West, thus her finding accounts for the centrality of the verbal icon "mentality" in everyday life in contemporary Romania.

The image of the "TTigan" is also rooted in Romanian history, and it assumed a renewed significance in relation to recent EU discourses promoting liberal Western values in Eastern Europe. As the historian Woodcock (2007b) discusses at length, the "Tigan Other" is a fantastic image constructed outside the ethno-national boundaries of Romania that emerges in moments of crisis. The experience of migration of many Roma from Romania has often been stigmatized by a large part of the Romanian media discourse, which claimed that with their behaviour Ţigani ruin the image of the country abroad (Rostas 2010). In view of the EU accession, in 2000 the Romanian government decided to change the passport code identifying the nationality from ROM to ROU, because ROM could have ruined the image of Romania abroad (namely in the West), as it resembles Roma. These recent events are the refractions of processes of marginalizing Roma, but also contribute to make marginalization possible. In light of this, marginality has to be understood here as a relational phenomenon, namely the result of persisting power dynamics, rather than a mere ecological, or socio-economic status (Brodwin 2003; Murray Li 2005). This conceptualization enables an open ethnographic analysis of the ways in which everyday stigmatization reflects marginality, while concomitantly ratifying it through peculiar strategic uses of verbal icons.

\section{"Mentality" in the context of social marginality}

Cluj, the capital of Transylvania, has a population of 318,000, and is today one of the most industrialized and richest towns of Romania (Ionică 2008). Its development boomed after the twelve-year term of office of mayor Gheorghe Funar (1992-2004), who promoted a strict economic protectionism predicated upon nationalist ideologies 
(Brubaker et al. 2006). After his mayorship urbanization and the economy started to grow rapidly, and the local housing market became afflicted by an increased demand. As in all Central and Eastern European countries, in each to a different extent, this development assumed the shape of a neoliberal project, with policies previously unknown in the region (Petrovici 2007; 2011). In 2004, for example, the local council started lowering yearly the budget of the Social Services department, while simultaneously supporting the police department by opening two new branches, namely the community police (poliţia comunitară) and the local police (poliţia locală). ${ }^{5}$ This West-led type of capitalist growth is today evident in many spheres of Clujean society, ${ }^{6}$ and it has led to the increased marginalization of the working-class urban population (Ibid. 2007). This development is palpable in urban planning strategies, especially in the case of the 2010 relocation of a group of forty low-income Romani families from the centre of the city to the extreme periphery, right close to the biggest local garbage dump.

When I arrived, in $2008,{ }^{7}$ I soon became aware of the two main issues that Romani Clujeni were facing. ${ }^{8}$ The first issue was the local garbage dump, out of which about one thousand Romani people were making a living. "An OSCE delegation just visited the garbage dump, declaring the necessity of applying for international grants in order to give these people ID cards", as Marius, ${ }^{9}$ who was employed in a local organization and introduces himself acknowledging Roma descent, told me. The lack of ID cards, and the consequent impossibility of using public services, was one among several problems related to the garbage dump, such as extremely bad hygienic conditions and children lacking primary education. The second main issue concerned discrimination that Roma faced in labour relations. As Marius told me in one of our first meetings, "often my colleagues take care not to use the usual vocabulary to address Roma [i.e. using Tigani] when they talk to me or just meet me in the office, and this is only a small example of how pervasive everyday stigmatization is".

In 2011 these two main issues were not only persisting, but became exacerbated. In December 2010 the local council decided to relocate around forty Romani families from the city centre close to the garbage dump, into small modular housing units built up ad hoc. In their previous location, some of the families were legally residing in flats, close to which other families were living in improvised and illegal housing.

5 Between 2010 and 2011 the number of Clujean families on social benefits fell from 170 to 110 . Moreover, The process of pluralization of police branches, aimed at addressing the sense of insecurity of majority society, happened in several Romanian cities, and was guided by Western police departments such as the Swiss one.

6 This is visible in the city centre, where many expensive and elegant cafés and restaurants recently opened.

7 I spent thirteen months doing fieldwork in Cluj., from March to July 2008 and from January to August 2011. I carried out sixteen semi-structured interviews with public employees at various levels of the municipality; participant observation and informal dialogues with some civil servant and with workers in Batik, a periphery marginal neighbourhood. I also met with many Clujeans in several and unaccountable occasions, some of whom for small chats, such as taxi drivers, and some others for close friendship. While in the field I have always been speaking Romanian, the language every Clujean speaks.

8 Official census figures show that Roma constitute about $1 \%$ of the urban population.

9 The names of persons and urban locations have been changed by the author of this text. 
As the social worker helping the families living in the modular housing told me, the stramutarea ("resettlement", translated by some local activists as "eviction') led to a steep deterioration of each family's living conditions, primarily due to the proximity to the garbage dump's waste. About the second issue, Marius was no less upset, and one of his friends - Roma himself and activist in a local Roma organization, told me that "popular racism has grown and undermines more than ever before the livelihoods of Roma. Structural factors, such as the current global debt and economic crisis, he added, influenced this worsening process, and in general if you are Roma and if you search for a job things are much more difficult now than a few years ago".

My visit to the garbage dump and my encounters with Andrei in spring 2008 illustrate more vividly the extent of the pervasiveness of marginality, as well as everyday stigmatization. After having gone through the tortuous bureaucratic procedures for getting a certificate in order to make an official request to have a meeting with public employees, I can finally shake hands with Andrei, a man in his early 40s, in the communitarian police office. He is one of the officers who some years before participated in one of the many EU-funded projects for the inclusion of Roma and this is why his boss selected him for meeting me, after seeing my official request. As soon as we meet, Andrei starts telling me about the garbage dump, offering me a car ride to the dump, where I have not been yet. His car takes us about twenty-five kilometres out of town. When we approach the dump and start climbing to the top, the landscape appears to me a world apart. I can't only see a mountain of waste, but a broad plateau of garbage.

Trucks arrive periodically and discharge tons of all kinds of material that groups from five to ten people of all ages sort out and pick up, and either take it home or consume it right there. At the perimeter of the dump, down the hill, I can see a group of little houses, placed in three parallel rows, each row made of about ten houses. They look like improvised shanties that had been recently covered by concrete. The houses that I can see on the garbage hill, on the contrary, are not organized in groups, but dispersed at a distance of about fifty metres from each other. They are improvised shanties, made of cardboard, wood and metal sheets without any sign of refurbishment. The green and fascinating valley that forms the background recalls bucolic scenarios and makes the foreground scene appear rather surreal. On one of the pathways on the plateau, Andrei waves his arm to a man in his 30s, and stops the car. They have a short conversation, from which I sense familiarity between them. Andrei tells me that now there are more than four hundred people living on the dump or at its perimeter and that they have been there for forty years. Many of them are from Cluj - a very important detail. In Romania property and social rights are locally structured, so that you can enjoy them only inside the municipality where you reside.

On our way back to the city, we head by car to just outside the perimeter of the dump, towards a nearby group of modular houses located by the railway. Before arriving at the spot, Andrei tells me that there are only Roma families living there, and that few years ago they were resettled there from the city centre by the city council. They were living in houses that did not belong to them, and although it was illegal to live so near to the railway, the municipality did not know where else to resettle them. "At the time of the resettlement there were twenty three families, but today they are one hundred 
and thirty", Andrei tells me. As we arrive, he starts shaking hands with adults, who welcome us in their houses.

The site is equipped with small containers, of the kind that is used to host earthquake survivors; they are geometrically arranged, some of them surrounded by improvised shelters or shanties, as well as by piles of different kinds of scrap materials; the site is evidently overcrowded, and the dimensions of the houses encourage - or rather oblige the occupants to socialize in the public space. Some of the inhabitants show us around, explaining what their major problems are. They tell us that the heating is insufficient, and that they don't know what can happen to them should they remain there another winter. Yet what they seem more concerned about, is their future housing location. "What is going to happen to us?", they keep on telling us. Andrei explains to me that a new orbital road is planned exactly on the piece of land occupied by these families. So they know they will have to move again at some point.

This is the end of our visit to the dump area, and we proceed by car to the city centre. On our way, we see in front of us a man riding a little wagon towed by a horse. On the wagon there is an old washing machine and it is inconceivable that this still works. Andrei looks at me and says:

You see? Tigani! Probably he found that washing machine in a bin, and he's going now to sell its components at the market. This is their job. The fact is, that they complain about not having jobs; we help them find one, but after a time they lose it and become unemployed again. Of course a job requires a strict timetable and a certain self-discipline. And of course it's easier to pick up scrap metal, sell it on, and eventually beg.

Andrei's ideas about Roma give us the opportunity to talk more in detail about the Romani families living in the modular housing we had just visited. I ask if the fact that there are Romani families living in unsafe conditions close to a garbage dump is a problem for him. He replies affirmatively, pointing at two possible solutions.

The first is that authorities don't have enough realistic sanctions in order to treat Tigani in the same way as they would any other citizen. For example, if I exceed the speed limit on the highway, I receive a penalty. If I don't pay the penalty someone would come to my house and would confiscate my possessions. This is a law for everyone. The problem is, they don't have houses, they don't have a bathroom, and they don't have anything. And so, even if you give them a penalty you cannot make them pay it. Moreover, the rich Tigani don't have to work. They've got this mentality. I was talking to them, and they told me: "What? Work? You work, not me!" The second solution, according to him, overlaps the first one as it is about "giving them [Roma] the resources for living decently. But even if you give them the conditions, they are not capable of using them. I saw it there. We gave them these modular small houses, and they asked for wood, so we gave them wood, and when we arrived there, we said, "Ok, the wood is here. Please help us unload the track, it's cold out here!" They replied: "Unload? Us? " Do you understand [talking to me]? Their mentality is to have it unloaded.

While our visits to the dump and to the nearby community tell about the first issue concerning Roma in Cluj, Andrei's use of "mentality" captures the second one, i.e. the everyday idiom of difference. Andrei's ideas on how to solve the problem of marginality 
are quite widely widespread among civil servants. In Andrei's talk, there are three main meanings of "mentality". The first is that "mentality" of (all) Roma is not simply one of the conditions of marginality. Since, according to Andrei, it is up to all Roma to emerge from their own condition of marginality, their "mentality" is the ultimate reason for that condition. Its second meaning is that it is related to Roma's (again, all Roma, rich and poor) supposedly defective work ethic. Finally, in our discussions "mentality" emerged only in relation to how to solve the situation of marginality of those Roma, and it served Andrei's argument of the impossibility of such improvement. Therefore "mentality" is filled also with the third meaning of preventing improvement of the condition of marginality.

In 2011 (Roma's) "mentality" seemed to still be the main explanation of the social marginality of Roma. As I arrive in town, I find out about the stramutarea that happened in December 2010. The reason for the municipality to resettle about two hundred Romani Clujeni was that around half of them did not have regular contracts. I soon became interested in knowing more about the resettlement measure and I fixed a meeting with Irina, the head of a municipal department and one of the civil servants who coordinated the entire operation. My dialogue with Irina accounts for the persistence in 2011 of the pervasiveness of "mentality" in providing a self-evident truth for explaining the condition of marginality that ever more Romani Clujeni face.

Following a couple of brief meetings, at our third meeting she allows me to record an interview concerning the recent decision of resettling. After telling her that I saw the unsafe hygienic and material conditions in which people were living in and around the garbage dump, I ask her whether she thinks that the recent resettlement had a positive impact on the everyday life of those Romani families.

You should also see who are the people targeted by this policy. I wonder, what is their mentality? That's because a public policy can be very good, but if it's not applicable, meaning that the people for whom it is designed to be implemented see reality in a completely differently way... then everything becomes complicated.

Our conversation goes on and I ask her, as I did with Andrei, what she thinks a sustainable solution for social integration may look like. She replies:

The way I see the integration of Roma? Well, they should stop having this mentality of an oppressed minority. They should begin to compete with other citizens; they should begin to ask for rights; to go to school and behave like the other children; to go and look for jobs with the others, and to integrate in their social surroundings.

Irina's meanings of mentality partially differ from Andrei's ones. Firstly, Irina does not strictly link mentality only with work ethic. However, she does include laziness in her expression, pointing out that Roma should compete with other citizens. Secondly, Irina envisages the necessity for Roma to ask for rights, which did not appear in my conversation with Andrei. And finally, by saying “... the people [Roma] [...] see reality in a completely different way" Irina significantly uses "mentality" as synonymous with "ways of seeing reality", she stresses an ultimate difference between Roma and the majority society. 
This meaning of ultimate difference fills also Florin's concept of mentality in relation to Roma. One of Irina's colleagues, and the head of another municipal department, Florin did not have any role in the resettlement. Nevertheless in his job he deals on a daily basis with a number of Romani Clujeni. When we met in 2008 for the first time, I asked him about his general ideas on Roma and his own idiom of difference emerged:

They have certain traditions, which separate them from the others, and which make them difficult to be integrated, because they refuse this integration. Due to their behaviour and their ways of being, they exclude themselves. The only means of integration for this group is education.

When I then asked him whether in his opinion integration meant that public authorities should provide education, he replied,

No, integration is accepting an obligation by a certain group or community visà-vis a certain environment. For example, if I go to the U.S., it is essential for me to learn their language in order to respect institutions.

We then naturally arrive at the issue of why Roma, according to him, exclude themselves.

The problem is that, for example, after the revolution [1989] the Dutch built houses for Roma in the north of Romania, and some years later, Roma put horses inside their own houses. You see? This is partially explained by the fact that under Ceausescu Roma had everything; they did not have to worry about anything. The authorities used to tell them: "just do what we say". This tendency of waiting for what the state or the administration will "give us [Roma]", this mentality still exists.

In 2011 I met Florin only once for a chat about the recent resettlement. He explained me that

Roma have some traditions, or mentality, due to which it's hard for them to change [...] What is the problem in Romania? As you know, we do not carry out policies, which discriminate between ethnic groups. That is done in order to avoid negative discrimination. Now, in the census many Roma do not declare themselves as such, but it's evident that they are Roma. It's evident by looking at their behaviour, at their customs...but they do not declare themselves as Roma. How can I tell you? In the case of Roma, the man walks in front of the woman, who walks about two steps behind him. You see? Roma's mentality and style of behaviour is different [from that of the majority]. It's rare to see a [Romani] man and woman walking hand in hand.

When we get to the point of how integration might be possible, he states again what he told me three years before, namely that only with education something could have been achieved: "Integration means education, which means qualifications and getting a job. Without this it is not possible to be integrated. And education brings with itself qualifications and a change in mentality". And what does a change in mentality mean? 
I ask

This means, "Since I am Thigan, I am allowed to do this and that!" And in order to change this [attitude] it might also be that we need to change our mentality. Probably change should come from both sides, i.e. we and they.

Florin here reproduces Andrei and Irina's uses of mentality, although he adds one further element, assuming the possibility of changing the mentality of the majority ("it might also be that we need to change our mentality'). This implies a change in perspective, as mentality is here also used in referring to the (Romanian) majority.

According to Heintz (2002), "mentality" in the Romanian space has two main meanings. One, resembling Lévi-Bruhl's (1910) research, is connected with the classic conception of ethnopsychology according to which "mentality is the structure of thought proper to an ethnic group" (Heintz 2002: 3). In this view, mentality is synonymous with the fixed concept of "nationality" and it refers to ideas of an unchangeable essence that a group allegedly bears, and draws historically on the most popular philosophical tradition of ethno-nationalist elite construction, such as Constantin Noica. The second meaning is instead synonymous with the more fluid concept of "culture", and therefore it is related to change. In both meanings, mentality is the ethnic essence shared by all Romanians, but only in the first meaning it is predicated upon unchangeable ethnonationalist feelings and values. According to Heintz, the expression "Romanian mentality" in everyday life in Romania is mostly filled with the second meaning, and it is widely used in order to explain historical macroeconomic failures, such as entering the NATO in 1997.

However, as my encounters with Andrei, Irina and Florin suggest, the meaning of the expression mentalitate in relation to Roma in Cluj is more often of the first kind rather than of the second; it is an unchangeable essence, consisting of laziness and backwardness, that ultimately ratifies, in everyday banal interactions, the exclusion of Roma from the imagined ethno-national space. Beside a few abstract normative views, such as Irina's about the necessity for Roma to compete and ask for rights, I did not encounter the belief that Roma are actually able to emerge from their alleged position of inferiority. A prevalent meaning related to a defective work ethic expressed in a general laziness and backwardness, due to Roma's alleged cultural traits was what I almost always came across.

\section{“Țiganu-i Țigan" in the local economy of taxonomies}

It was during long and continuous conversations in Batik, a post-industrial neighbourhood on the city outskirts, that I came across the icon Tiganu-i ţigan'. ${ }^{10}$ I chose Batik because I aimed to study the everyday idiom of difference as applied to Roma in a context where people had regular contacts with them, and Batik was the neighbourhood with the largest presence of Romani households. For this reason Batik

10 Batik (pseudonym) is one of the most evident examples of the post-1989 rapid restructuring of Romanian economy. A typical industrial neighbourhood, it is nowadays a so-called cartier dezvoltare, (developing neighbourhood). One of the most outstanding signs of such development is the 2007 construction of a shopping mall in place of a brick factory. 
is derogatorily stigmatized in the city as "cartier ţigan" (Tुigan district) and associated with danger. There I was regularly meeting two groups of Batikeni - male workers in a pub, and shopkeepers in their shops or in nearby cafes. I used to present my research as an investigation into Batik's social life, without explicit reference to my interest in the idiom of identification and difference with regards to Roma. This allowed me to understand the extent to which Roma entered the discourses on the neighbourhood's social life. Without much surprise, all my interlocutors pointed out the presence of Roma as one of the fundamental local problems, and articulated their views on them. My position as a Western, and especially Italian, adult researcher influenced my interlocutors' talk: they often brought the topic of Roma's recent westward migration in the conversation. In Batik there are three areas in which Romani households can be found, and there is also one Pentecostal church where a number of Romani families gather for the weekly service. These geographical and religious coordinates give Batikeni solid and precise sources for differentiating within the large ethno-category of Roma; in other words, for creating folk taxonomies of Roma.

During my 2008 visits to Masuri, the pub in Batik where I was meeting male workers after their shifts, I recurrently encountered one taxonomy in different guises and shapes. "They don't work", Sorin says. "They take our money and don't work, because they don't want to, they are not Romanians. You [Italians] in Italy have problems with Ţigani”. I tell him that there are Roma in Italy who have Romanian passports, and he replies that it doesn't matter, because

We are Romanians, they are Tigani. Tiganu-i tigan, as we usually say. But not all
Tigani are the same. There are Rromi, who are usually street cleaners and live in
little houses, and there are Tigani, who trade in livestock and have big houses.
Tigani sometimes happen to be rich, they have villas, and so on. Also, Rromi
emigrate more often than Tigani. Finally, there are Gabor, who have "culture",
they produce clothes and Gabor women knit the long skirts they usually wear.

Almost all taxonomies I encountered reproduced this hierarchy: Gabor, the most "regular guys", who have their business and traditions and do not make too much noise; Rromi, who have low-paid jobs and are generally very poor; and Ţigani, who are the worst because they are not highly educated and are inclined to steal, but at the same time some of them are very rich, living in big palaces. However, some exceptions occurred, one of which more often than others.

The director of a shop inside the newly constructed shopping mall introduced a slightly different categorization. He told me that Batik's social life was dominated by Țigani, "who are the cause of the current urban decay. This is because Țigani are neoameni, they do not work and they are dirty. This is the major problem in Batik - Ţiganu-i țigan. But not all Ţigani are the same. For example, Gabor are not Țigani, because they are dressed in a proper way and they are not dirty". The appropriate translation of "neoameni", literally "non-humans", varies between "monster", "inane person" and "non-entity". In everyday interactions I had already come across this attribute, which a taxi driver a couple of weeks earlier while talking to me ascribed, again, to Roma. Although it would be imprudent to delimit my interpretation to one of the three possible translations, it does seem plausible that the most radical one, "non-entity" plays a dominant role; it holds a denial of human sameness exceeding the 
widely shared categorization of Roma such as "Rromi, Țigani and Gabor". In Brubaker \& colleagues" (2006) work, these three categories fall into the "category set" (2006: 213) of human beings. ${ }^{11}$ Conceiving Roma as not belonging to the humankind positions them outside of this category set.

This radical interpretation is substantiated by my field experience in Batik. During my conversations in Masuri, my acquaintances were telling me about social communication codes for drinking in a pub with friends; about the history of local gangs, of their famous leaders, and also about the most popular expressions for describing Batik's social ethic. One such expression was "Om e om" (literally "a man is a man'), and recalls not only popular values of masculinity such as physical assertiveness and comradeship, but also more universal values related to work and responsibility. Importantly, "om" in Romanian means both "man" and "human being", and, in light of this, the passage from Tiganu-i tyigan to "Thigan is not an om" does not seem meaningless. Therefore, the shopkeeper may have pushed the meaning of Tiganu-i țigan to the extreme, with the result of excluding Roma not only from the national space, but from humankind altogether. ${ }^{12}$

A more historically nuanced understanding of the social uses of "neoameni" when referring to Roma, can be inspired by Mauss" (1938) essay on the notion of person and of "myself" [moi]. By going back to the origins of Roman Law, simultaneously looking at the contemporary social uses of the category of "person" in theatrical and everyday life, the anthropologist explains:

Parallel to [the juridical thought] the word "person", artificial character, mask and role of comedy and tragedy, of slyness, of hypocrisy - from the stranger to "myself" - kept being used. Yet, the personal character of Roman Law was founded, and persona also became synonymous with the true nature of the individual. Concomitantly, the right to the person was founded, and only the slave was excluded from it. Servus non habet personam. [The slave] does not possess personality, he does not possess his own body, he does not possess ancestry, name, cognomen, nor he possesses his own goods. (Mauss 1938: 274; my translation)

The difference between person and slave, as depicted by Mauss, can reasonably serve as a ground for interpreting "neoameni". Although this interpretation may sound excessively distorted as to turn it into a functional basis for my argument, it resonates with similar accounts in other parts of the world. In his essay meaningfully entitled Non-persons (2009) Dal Lago explains that the social conditions of undocumented migrants in Europe can be heuristically understood by referring to Mauss' work on the category of "person". Dal Lago outlines in depth the condition of "non-existence" to the eyes and bureaucratic structures of Western democracies, that undocumented

11 As well as in a sub-set that I here may call ethnicity, but although this is the kind of set that Brubaker \& colleagues use, using it does not seem to be relevant for the purpose of this discussion.

12 I can account for a further evidence of this interpretation. In March 2009 I was interviewed by the national newspaper Cotidianul about my ongoing fieldwork in Cluj. The interviewed was published with the title "Romanians" perceptions: "Thigani" are "neoameni" for us'. After one week that the article remained on the newspaper's website, I counted more than sixty comments posted by readers. Almost all comments interpreted the word "neoameni" as "inhuman", throwing radically derogatory messages denying personhood to Roma. See Cotidianul, 5 march, 2009. 
live in. Although in Romania Roma hold national citizenship, the everyday uses of neoameni can be understood as a comprehensive and complex array of historical legacy of slavery, ${ }^{13}$ along with deep-rooted prejudices and stigma currently affecting Roma in the country and beyond.

The current use of the verbal icon Thiganu-i ţigan is the reverberation of a long history of stereotyping Roma in Romania, and this is why it is hardly translatable with "Gypsy". ${ }^{14}$ For the whole period during which Roma were slaves, namely from the end of the $13^{\text {th }}$ century - when Roma arrived in Romania - to the mid $19^{\text {th }}$ century (Achim 2004), "Țigani” was used as synonymous of slaves. As Gheorghe (1997) notes,

The codification of Gypsy slavery became clearer towards the $18^{\text {th }}$ century. Tigan in the Romanian language was equivalent with rób, which might be translated as "slave". (1997: 158)

Moreover, according to Woodcock (2007a), who is the first scholar focusing systematically on the cultural history of the gaze upon Țigani in Romania, "the Țigan Other" played a key role in the $19^{\text {th }}$ century building of the modern Romanian state. Popular images of Roma lacking intelligence and being lazy, immoral and uncivilized were opposed to the hard-working Romanian peasant, who was the emblem of the national character. Later, during the interwar period, Roma were kept out of the imagined Romanian community by means of racialization. The theories coupling social deviance with biological heritage, initially developed by Cesare Lombroso (1886), became popular in constructing the biological Tigani. In the socialist period, Tigani became viewed as parasites in opposition to the hard working socialist women and men, and after 1989, they embodied the ultimate Mafioso characters. Finally, with the beginning of EU accession discourse, which started in the mid 1990s by framing Eastern European Roma as cultural - and often nomadic - objects (Simhandl 2009), Tigani became gradually perceived as a threat for the image of Romania abroad.

Sorin's initial preoccupation with establishing a fundamental difference between Romanians and Ţigani partially stems from this for, as he had pointed out, "you have many problems in Italy with Ţigani". Indeed, the main destination of Romanians traveling abroad since the 1990s has been Italy, followed by Spain. This is one of the occasions in which I experienced that my nationality was significantly influencing workers' talks. This created a sort of bias in my interest in Romanian Roma, who - in the eyes of my interlocutors, who indexed Roma to criminals, expressions which were clearly taken by mainstream media (for instance "ei fac scandauri') - resembled a way of understanding where my country's alleged "public enemies" (Sigona 2008) were coming from. This is an everyday refraction of a widely widespread perception in Romania of "Western" values as being better than Romanian ones. In this scenario, the Tigan occupies the role of ratifying the boundedness of nationhood, both through the icon "Thiganu-i țigan" and through explicit blame by the media.

13 Roma in Romania were confined to slavery for over six centuries, from their arrival (1241-42) to 1864, when the first law abolishing slavery passed (Achim 2004).

14 This is mainly, but not only, because "Gypsy" is a much more polisemic word than Țigan, due to the fact that it has different meanings in different English-speaking countries, such as Britain, Australia, and North America. 


\section{Iconicity, the "West", and cultural intimacy}

Contextualizing the role of Țigan as a tool for the construction of nationhood in the late 2000s Romania can be a valuable standpoint for discussing my ethnographic findings about the uses of the two verbal icons in Cluj. Heintz's $(2002 ; 2004)$ understanding of why in Romania middle-class employees deploy the category "Romanian mentality" to blame the macroeconomic failure of Romania is similar to the one that Woodcock (2007b) puts forward as to why people construct the image of the "Tiigan Other". Heintz argues that the "mentality explanation" of economic crises is a sign of low selfconfidence (or self-respect):

Blaming the "Romanian mentality" for everything that goes wrong is the reflection of this lack of self-respect at both the individual and the national level and it is in this quality that it has an explanatory power. (Heintz 2002: 212)

On the other hand, Woodcock (2007b) explains the construction of the scapegoat Ţigan as a response to a "sense of inability to perform European identity [and this] throws into relief the highest stakes involved in maintaining the image of European origins through the Țigan Other" (2007b: 503). Both explanations clearly imply the inadequateness vis-à-vis what are perceived as Western values, attitudes and habitus. However, in the case of mentalitate with reference to Roma, and Tiganu-i ţigan, we are confronted with a third way of making sense of social reality. My interpretation of the use of these two icons builds on the work of the two scholars but also refers to Michael Herzfeld's idea of "cultural intimacy".

In addition to exclusively resulting from a sense of inadequacy, as Heintz and Woodcock suggest, I would argue that mentality, when referred to Roma, stems from a wider social and historical background revolving around an emergent neoliberal paradigm which is refracted in recent and current policy making. The concept of icon is particularly heuristic here, because the rhetorical use of "mentality" referred to Roma aims to give an impression of static, eternal consistency and thus narrative coherence, with the ambition of explaining social marginality by reference to supposed in-group characteristics of Roma. This does not mean that Andrei, Irina or Florin never took into account the structural conditions leading to the marginalization of Roma, but my encounters with them illustrate that even when they acknowledged these conditions, and expressed a sincere empathy and concern for marginalized Roma, they gave an explanation, which was compatible with the usual everyday icon of mentality. Attributing the ultimate cause of marginality to the marginalized's work ethic is a distinctive feature of emerging neoliberal discourse in Europe, which tends to overlook contextual socioeconomic conditions in favour of "responsibilising" citizens about decisions that public authorities impose on them (see Nyqvist 2011). A similar interpretation holds true for the uses of Thiganu-i țigan within the economy of local taxonomy. As my data shows, in this case too - although much less reflexively - the responsibility for being outside the imagined national community, and - at its extreme - outside humanity altogether, is seen as lying exclusively with the Roma themselves.

However, there are important differences between the two icons. Cultural difference is anchored in, and becomes socially meaningful in relation to, social experience and "the cognitive distinctions in terms of which experience is ordered" (Bentley 1987: 
36). In the case of mentalitate, the experience and its cognitive mediation were clearly referred to work ethic. While deploying the concept of mentalitate, my interlocutors were referring to their own concrete experiences with Roma, who were seen by my interlocutors as unable of working adequately, mainly due to their supposed lack of will to do so. Instead, Thiganu-i țigan, notwithstanding the scene at the RomTelecom office, was less related to first-hand experiences, being rather the product of a holistic abstraction conceiving the lack of belonging to the ethno-national community. Rather than being "at work" in some circumstances and not being "at work" in some others (Brubaker 2004), Roma's ethno-national (non) belonging was affirmed as a sort of constantly present background local knowledge. On the contrary, mentalitate emerged during my dialogues about work and work ethic, and never arose while discussing different topics.

Another necessary background element to the formation of my interpretation is the role of the "West" in everyday iconicity. How does blaming Roma for their social conditions relate to the image of the "West'? This question forces to see the "West" as an icon itself. Almost all the middle-class Clujeni employees that I had the chance to meet were telling me about the lack of discriminatory legislation and practices vis-à-vis Roma in every sphere of social life, as I showed while discussing my 2011 meeting with Florin. This disclaimer of non discrimination can be understood within the context of the EU discourse on Roma. Since the first discourses on enlargement during the 1990s and the consequent emphasis on minority rights in order to prevent a mass westward migration of Roma, Romanian authorities have been under pressure to meet the necessary criteria. One of the main criteria for EU membership has been the eradication of discrimination, especially against generally deprived minorities such as the Roma, and the protection of all other basic human rights.

In light of such pressures coming from the EU, in the Romanian context the everyday idiom on minorities, and especially on the most vulnerable one such as the Roma, was rearticulated creatively in defensive ways. In fact, the two verbal icons can be seen as not only part of the historical legacy of scapegoating Roma, but also as serving the contingent socio-political need of constructing a free and uncontested national space vis-à-vis European diktats and criticism about the ways "we treat our Roma". Having to comply with international standards, a peculiar local jargon among civil servants can keep alive the informal, everyday ways of excluding Roma from ethno-national boundaries. This becomes possible thanks to two main culturally shared values, which are crucial in giving the two icons the power of continuously policing ethno-national boundaries. The first value is what Heintz calls "an exaggerated respect for everything that is Western" (2002: 11), and it becomes functional inasmuch as it provides the expression "mentality" - generally used either to praise its "Western" character (Western mentality), or to criticize the "Romanian one" (Romanian mentality) - with a meaning holding Țigani responsible for their own social condition of marginality. The second value concerns the capacity of both icons to dissimulate their own exclusionary meanings and social values because they are not overtly disrespectful expressions. It is indeed unlikely that "Western" observers would grasp the social meanings and values attached to mentalitate and Ţiganu-i ţigan unless delving deeply in Romanian cultural history and ethnographic present. Indeed, the two icons do not seem to bear any intention of insulting or overtly excluding someone from the ethno-national community. What 
the two icons ultimately serve is rather the interest of ratifying the condition of social marginality in which many Clujean Roma live.

This leads to consider iconicity in Cluj with regards to Roma as a peculiar instance of cultural intimacy. It is in fact this sort of iconicity - either expressed through representations of Roma's work ethic, or encapsulated in an exclusionary ethnonational cosmology - that allows the preservation of a national social space, which is able to provide some of the necessary symbolic resources for a shared sociality. Partially different from Herzfeld's conceptualization, the peculiarity of this instance of cultural intimacy is that beyond the gaze of the state, there is the gaze of the "West", and specifically the powerful gaze of the EU. This might allow the concept of "cultural intimacy" to migrate beyond both the nation-state, as well as beyond this particular article, towards settings in which supranational powers and globally shared prejudices exercise considerable influence on everyday forms of sociality.

\section{Conclusion}

This article has contributed with empirical and theoretical material to research on the links between social marginality and everyday idiom of cultural difference in post-socialist Europe. It did so by considering two popular everyday expressions, i.e. mentalitate and Thiganu-i ţigan, used for identifying Roma in everyday Clujean social life, as icons (Herzfeld 1997: 93-110), namely static images indexing values such as laziness and backwardness. In the ethnographic discussion I provided evidence showing that the two icons are vividly present in contemporary Romania and that they serve the goal of keeping Roma outside the (moralized) imagined boundaries of the nation. Building on the work by Heintz (2002; 2004) and Woodcock (2007a; 2007b) I provided an interpretation of "iconicity" in the Romanian context that accounts for a peculiar instance of cultural intimacy. This instance is predicated upon a twofold dynamic, visà-vis which a defensive and concomitantly creative attitude unfolds. On the one hand, the ideological gaze of the EU's liberal discourses of minority rights; on the other, the long history of scapegoating Țigani that provides a cultural repertoire for keeping them outside the boundaries of the nation. This intimate cultural and social space in which everyday exclusion becomes possible, is key in shedding a more comprehensive light on the logic of marginalization of Roma in contemporary Eastern Europe.

Talking about the difficult postcolonial transitions that Morocco and Indonesia undertook, Clifford Geertz, who founded an "interpretative science in search of meaning" (1973: 5), located his own interest as anthropologist in the study of power, by asking the question, "If (as is supposed) the state drives the country, what (are we to imagine) drives the state?" (1995: 26). Similarly, through an analysis of the social meanings and uses of verbal icons, in this article I discussed what contributes to "drive" local policies vis-à-vis Roma in post-socialist Europe. The two icons are not only different in use - mentalitate more reflexive and attached to experience whereas Tुiganu-i țigan more intuitive and detached from any particular experience - but also in their order of meaning. While the former alludes to a problematic generic character that in principle, as Heintz (2002) argues, is acknowledged as being shared by all Romanians, the latter is a more bounded and coherent expression. Its sounded symmetry resembles more 
a philosophical aphorism than an offence and it is able to synthetically convey the contours of a self-evident and coherent social hierarchy.

Within the framework of the recent and steadily increasing neoliberal stances in policy-making, I shed light on the relationships between social marginality and the everyday idiom of difference, which is shared by policy makers and the urban population at large. The embodiment in everyday life of historically rooted forms of stigmatization of Roma "works", quite silently but nonetheless effectively, in perpetuating Roma's alleged incommensurable difference from non-Roma, and ultimately ethno-national hierarchies. And specifically, civil servants' icon of mentalitate with regards to Roma discloses the centrality of lay, banal perceptions behind policy-making and in general administrative behaviour vis-à-vis low-income strata and groups. ${ }^{15}$

\section{References}

Achim, V., 2004. The Roma in Romanian History. Budapest: Central European University Press.

Bentley, G. C., 1987.“Ethnicity and Practice”, Comparative Studies in Society and History 29 (1): 24-55.

Berescu, C., 2011. "The Rise of the New European Roma Ghettos: A Brief Account of Some Empirical Studies", Urban Research and Practice 4 (3): 344-352.

Bringa, T., 1996. Being Muslim the Bosnian Way: Identity and Community in a Central Bosnia Village. Princeton: Princeton University Press.

Brodwin, P., 2003. "Marginality and Subjectivity in the Haitian Diaspora", Anthropological Quarterly 76 (3): 383-410.

Brubaker, R. 2004. Ethnicity without Groups. Cambridge, MA: Harvard University Press.

Brubaker, R., M. Feidschmit, J Fox \& L. Grancea, 2006. Nationalist Politics and Everyday Ethnicity in a Transylvanian Town. Princeton: Princeton University Press.

Cioroianu, A., 2002. "The Impossible Escape. Romanians and the Balkans”, in D. Bielik \& O. Savic, (eds), Balkan as Metaphor: Between Globalization and Fragmentation. Boston (Mass.): The MIT Press.

Dal Lago, A., 2009 [1999]. Non-persons. The Exclusion of Migrants in a Global sSociety. Milan, Italy: Ipoc Press.

Deoanca, A., 2009. “Perceptia Romanilor: ‘Tiganii’ sunt 'neoameni’ de langa noi”. Cotidianul, 5 march.

Emigh, R. J., E. Fodor \& I. Szelenyi (eds), 2001. Poverty, Ethnicity and Gender in Eastern Europe during the Market Transition. Westport, CT \& London: Praeger.

Eurostat, 2009. Income Distribution Statistics. Avalaible at: http://epp.eurostat.ec.europa.eu/

Gay y Blasco, P., 2003. “ 'This Is Not a Place for Civilised People': Isolation, Enforced Education and Resistance Among Spanish Gypsies”, in A. Bashford \& C. Strange (eds), Isolation: Practices and Places of Exclusion. New York: Routledge.

Geertz, C., 1973. Interpretation of Cultures. New York: Basic Books.

-, 1995. After the Facts. Two Countries, Four Decades, One Anthropologist. Cambridge, MA: Harvard University Press.

Gheorghe, N., 1997. 'The Social Construction of Roma Identity“, in T. Acton (ed.), Gypsy Politics and Traveller Identity, 153-163. Hatfield: University of Hertfordshire Press.

15 There are several anthropological studies on the centrality of (mis)representations of Romani people behind policy making in Western Europe (e.g. Gay y Blasco 2003; Picker 2011; 2013) but I am not aware of similar studies in Eastern Europe. 
Heintz, M. 2002. Changing Work Ethic in Post-Socialist Romania. Pdh Diss., University of Cambridge (UK).

-, 2004. “Be European, Recycle yourself!” The Changing Work Ethic in Romania. Berlin: Lit Verlag.

Herzfeld, M., 1997. Cultural Intimacy. Social Poetics in the Nation-State. London \& New York: Routledge.

Horvath, K., 2010.“'Passing”: Rebeka and the Gay Pride. On the Discoursive Boundaries and Possibilities of Skin Colour", in M. Stewart \& M. Rovid (eds), Multidisciplinary Approaches to Romany Studies, 123-130. Budapest: Central European University Press.

Ionică, F., 2008. "Nokia face din Cluj cea mai fierbinte zona pentru investitii din Europa", Săptămanâ Financiară, 18 January.

Jansen, S., 2003. "Why do they hate us? Everyday Serbian nationalist knowledge of Muslim hatred", Journal of Mediterranean Studies 13 (2): 215-237

Kligman, G., 2001. On the Social Construction of "Otherness" Identifying "the Roma" in Post-Socialist Communities, Review of Sociology 7 (2): 61-78.

Kovai, C., 2010.“On the Borders of Gender. Marriage and the Rome of the 'Child' amongst Hungarian Gypsies”, in M. Stewart \& M. Rovid (eds), Multidisciplinary Approaches to Romany Studies, 108122. Budapest: Central European University Press.

Ladanyi, J. \& I. Szelenyi, 2006. Patterns of Exclusion. Constructing Gypsy Ethnicity and the Making of an Underclass in Transitional Societies of Europe. New York: Columbia University Press.

Lemon, A., 2000. Between Two Fires. Gypsy Performance and Romani Memory from Puskin to Postsocialism. Durham \& London: Duke University Press.

Levy-Bruhl, L., 1910. Les fonctions mentales dans les sociésés inférieures. Paris: Presses Universtitaires de France.

Lombroso, C., 1886. L'uomo delinquente studiato in rapporto all'antropologia, alla medicina legale ed alle discipline carcerarie. Milan: Hoepli Press.

Mauss, M., 1938. "Une catégorie de l'esprit humain: la notion de personne, celle de moi”, Journal of the Royal Anthropological Institute 68: 263-281.

Mc Garry, A., 2010. Who speaks for the Roma? Political Representation of a Transnational Minority Community. London: Continuum.

Murray Li, T. (ed.), 2005."Marginality, Power and Production. Analysing Uplands Trnasformation", Transforming the Indonesian Uplands. Marginality, Power and Production. London: Harwood Academic Publisher.

Nyqvist, A., 2011. "Sweden's National Pension System as Political Technology”, in C. Shore, S. Wright \& D Però (eds), Policy Worlds. Anthropology and the Analysis of Contemporary Power, 205-222. Oxford \& New York: Berghahn Books.

Okely, J., 1983. The Traveller-Gypsies. Cambridge: Cambridge University Press.

Peter, L., 2005. "How Extreme Marginalization Generates Ethnicity?", in W. Heller, P. Jordan, T. Kahl \& J. Sallanz (eds), Ethnizität in der Transformation. Zur Situation nationaler Minderheiten in Rumänien 99-118. Vienna-Berlin: Lit Verlag.

Petrovici, N., 2007. "Excluderea muncitorilor din centrul Clujului. Gentrificare într-un oraş centraleuropean”, Sociologie Românească 5 (3): 42-70.

-, 2011. “Articulating the Right to the City: Working-class Neo-Nationalism in Postsocialist Cluj, Romania”, in D. Kalb \& G. Halmai (eds), Headlines of Nation, Subtexts of Class. Working Class Populism and the Return of the Repressed in Neoliberal Europe, 57-77. New York \& Oxford: Berghahn Books.

Piasere, L., 2006. “Che cos'è un campo nomadi?", Achab. Rivista di antropologia 8: 8-16. 
Picker, G., 2010. “"Nomads' Land? Political Cultures and Nationalist Stances vis-à-vis Roma in Italy”, in M. Stewart \& M. Rovid (eds), Multidisciplinary Approaches to Romany Studies, 211-227. Budapest: Central European University Press.

-, 2011. "Welcome 'in'. Left-Wing Tuscany and Romani Migrants”, Journal of Modern Italian Studies 16 (5): 607-620.

-, 2013. "Sedentarization and 'The Right to Nomadism'. The Urban and Regional Fabric of Nomad Camps in Italy (1967-1995)". Zeitgeschichte 40 (5): 276-286.

Picker, G. and G. Roccheggiani, 2013. "Abnormalizing minorities. The state and expert knowledge addressing the Roma in Italy", Identities. Global Studies in Culture and Power. http://dx.doi.org/10.1080/1070289X.2013.854719

Rostas, I., 2010. “The responses of Romania to Roma migration”, paper presented at the conference Romani mobilities in Europe. Multidisciplinary perspectives. Oxford: University of Oxford, 15-17 January.

Sigona, N. (ed.), 2008. The "latest" public enemy: Romanian Roma in Italy. The case studies of Milan, Bologna, Rome and Naples, Research Report for OSCE. Available at: www.osservazione.org/ documenti/OSCE_publicenemy.pdf

Sigona, N. \& N. Trehan (eds), 2009. Romani Politics in Contemporary Europe. Poverty, Ethnic Mobilization, and the Neoliberal Order. London: Palgrave.

Simhandl, K., 2009. "Beyond Boundaries? Comparing the Construction of the Political Categories 'Gypsies" and 'Roma' before and after EU Enlargement", in N. Sigona \& N. Trehan (eds), Romani Politics in Contemporary Europe. Poverty, Ethnopolitics and the Neoliberal Order, 72-93. Basingstoke: Palgrave.

Soros Foundation, 2011. Roma Situation in Romania, 2011. Between Social Inclusion and Migration. Country Report.

Stewart, M., 2010. "Introduction", in M. Stewart \& M. Rovid (eds), Multidisciplinary Approaches to Romany Studies, 1-12. Budapest: Central European University Press.

Todorova, M., 1997. Imagining the Balkans. New York: Basic Books.

Tulbure, N., 2009. "Introduction to Special Issue: Global Socialisms and Postsocialisms", Anthropology of East Europe Review 27 (2): 4-18.

UNDP, 2007. National Human Development Report. Romania. Accessible online at: http://hdr.undp.org/en/ reports/national/europethecis/romania/ROMANIA_2007_en.pdf

Willelms, W., 1997. In Search of the true Gypsy: From Enlightenment to Final Solution. London \& Portland, Oregon: Frank Cass.

Woodcock, S., 2007a. "Romanian Romani Resistance to Genocide in the Matrix of the Tigan Other", Anthropology of East Europe Review 25 (2): 28-43.

-, 2007b. "Romania and Europe: Roma, Rroma and Țigani as Sites for the Contestation of Ethno-National Identity”, Patterns of Prejudice 41 (5): 493-515. 
